\title{
Controllable Anomalous n- and p-type Photo-Thermoelectric Effects of Platinum Oxide and Tungsten Trioxide Layers with and without Chromic Reaction
}

Kohei Shimoyama ${ }^{\dagger}$ and Hiroshi Irie ${ }^{*},+, \neq$

†Special Doctoral Program for Green Energy Conversion Science and Technology, Integrated Graduate School of Medicine, Engineering and Agricultural Sciences, University of Yamanashi, 4-3-11 Takeda, Kofu, Yamanashi 40o8511, Japan

‡Clean Energy Research Center, University of Yamanashi, 4-3-11 Takeda, Kofu, Yamanashi 400-8511, Japan

Contents

S. I. 1) Detailed procedure for XPS (Figures S1-S8, Tables S1-S8)

S. I. 2) Detailed explanation of process for obtaining number of absorbed photons (Figure S9, Table S9)

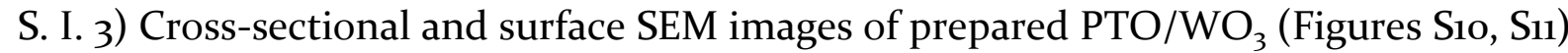

S. I. 4) Schematic diagram of $\mathrm{PTO} / \mathrm{WO}_{3}, \mathrm{H}_{y} \mathrm{WO}_{3}$ (Figure $\mathrm{S} 12$ ) 
S. I. 1) Detailed procedure for XPS (Figures S1-S8, Tables S1-S8)

The Pt $4 \mathrm{f}, \mathrm{W} 4 \mathrm{f}, \mathrm{Si} 2 \mathrm{p}$, and $\mathrm{O}$ is core levels were measured by XPS on the surface and in the inner region from the surface subjected to in situ $\mathrm{Ar}^{+}$etching of PTO (50 nm) on a $\mathrm{SiO}_{2}$ substrate, PTO (40 nm) on a Si substrate, PTO $(50 \mathrm{~nm}) / \mathrm{WO}_{3}$ on a $\mathrm{SiO}_{2}$ substrate, and PTO $(90 \mathrm{~nm}) / \mathrm{WO}_{3}$ on a $\mathrm{SiO}_{2}$ substrate to examine the percentages of $\mathrm{Pt}\left(\mathrm{Pt}^{\circ}, \mathrm{Pt}^{2+}+\mathrm{Pt}^{4+}\right), \mathrm{W}, \mathrm{Si}$, and $\mathrm{O}$. The obtained XPS profiles were calibrated with the $C$ is peak originating from a surface contaminant hydrocarbon that had a binding energy of $284.5 \mathrm{eV}$. When the $\mathrm{C}$ is peak was not detected as the etching process proceeded, which occurred in a couple of cases, the $\mathrm{W}_{4} \mathrm{f}_{7 / 2}$ peak derived from $\mathrm{W}^{6+}$ with a binding energy of $35.3 \mathrm{eV}$ was utilized for the calibration (such cases are not indicated here). ${ }^{\mathrm{A}, \mathrm{B}}$

To quantitatively evaluate the $\mathrm{Pt}^{0}, \mathrm{Pt}^{2+}$, and $\mathrm{Pt}^{4+}$ atomic percentages, peak deconvolution was performed using a Gaussian lineshape with the following parameters. The binding energies of $\mathrm{Pt} 4 \mathrm{f}_{7 / 2}$ and Pt $4 \mathrm{f}_{5 / 2}$ of $\mathrm{Pt}^{\circ}$ were fixed at $70.9 \pm 0.2$ and $74.1 \pm 0.2 \mathrm{eV}$, those of $\mathrm{Pt} 4 \mathrm{f}_{7 / 2}$ and $\mathrm{Pt} 4 \mathrm{f}_{5 / 2} \mathrm{of} \mathrm{Pt}^{2+}$ were fixed at $71.8 \pm 0.2$ and $75.1 \pm 0.2 \mathrm{eV}$, and those of $\mathrm{Pt} 4 \mathrm{f}_{7 / 2}$ and $\mathrm{Pt}_{4 \mathrm{f}_{5 / 2}}$ of $\mathrm{Pt}^{4^{+}}$were fixed at $72.8 \pm 0.2$ and $76.2 \pm 0.2 \mathrm{eV}$, respectively. The peak area ratio of $\mathrm{Pt}_{4 \mathrm{f}_{5 / 2}}$ to $\mathrm{Pt} 4 \mathrm{f}_{7 / 2}$ for $\mathrm{Pt}^{\mathrm{o}}, \mathrm{Pt}^{2+}$, and $\mathrm{Pt}^{4+}$ was fixed at $0.75 \pm 0.01 .{ }^{88,39} \mathrm{The}^{2}$ total $\mathrm{Pt}^{\mathrm{O}}, \mathrm{Pt}^{2+}$, and $\mathrm{Pt}^{4+}$ areas were determined by summing the corresponding deconvolution areas of $\mathrm{Pt}$ $4 \mathrm{f}_{5 / 2}$ and $\mathrm{Pt} 4 \mathrm{f}_{7 / 2}$. The total Pt area was determined by summing the total $\mathrm{Pt}^{\circ}, \mathrm{Pt}^{2+}$, and $\mathrm{Pt}^{4+}$ areas. Then, the percentages of $\mathrm{Pt}^{\mathrm{o}}, \mathrm{Pt}^{2+}, \mathrm{Pt}^{4+}$, and $\mathrm{Pt}$ were determined by considering the $\mathrm{Pt} 4 \mathrm{f}$ sensitivity factor $(5.575){ }^{C}$

Because the $\mathrm{O}$ is peak area on the surface (etching depth, o $\mathrm{nm}$ ) contains that derived from the surface contaminant hydrocarbon, only in the case of $\mathrm{O}$ is on the surface, the $\mathrm{O}$ is peak at $531.0 \pm 0.1 \mathrm{eV}$ originating from the lattice $\mathrm{O}$ fixed, and the peak deconvolution was similarly performed using a Gaussian lineshape. Then, only the $\mathrm{O}$ is area at $531.0 \mathrm{eV}$ and the $\mathrm{O}$ is sensitivity factor (11.2659) were utilized to calculate the percentage of the actual lattice $O .{ }^{B}$ Except for the $\mathrm{O}$ is on the surface, a very small amount of $\mathrm{O}$ is derived from the contaminant hydrocarbon was included because the $\mathrm{C}$ is peak was observed in most cases. However, such $C$ is peak areas were negligibly small; thus, the $O$ is peak area derived from the contaminant hydrocarbon was ignored and the measured $O$ is peak area was simply utilized to calculate the percentage of lattice $\mathrm{O}$.

The W4f and $\mathrm{Si}_{2}$ p peaks were not adopted in the peak-fitting method, and we simply utilized their peak areas. Then the percentages of $\mathrm{W}$ and $\mathrm{Si}$ were obtained by considering the sensitivity factor of 3.523 for $\mathrm{W} 4 \mathrm{f}$ and 0.339 for Si 2p, respectively. ${ }^{\mathrm{C}}$

\section{References}

(A) Blackman, C. S.; Parkin, I. P.; Atmospheric Pressure Chemical Vapor Deposition of Crystalline Monoclinic $\mathrm{WO}_{3}$ and $\mathrm{WO}_{3-x}$ Thin Films from Reaction of $\mathrm{WCl}_{6}$ with O-Containing Solvents and Their Photochromic and Electrochromic Properties. Chem. Mater. 2oo5, 17, 1583-1590.

(B) Solonin, Y. M.; Khyzhun, O. Y.; Graivoronskaya, E. A.; Nonstoichiometric Tungsten Oxide Based on Hexagonal $\mathrm{WO}_{3}$. Crystal Growth $\mathcal{E}$ Design, 2oo1, 1, 473-477.

(C) Bard, A. J.; Parsons, R.; Jordan, J.; Standard Potentials in Aqueous Solution, 1985, New York: Marcel Dekker. 

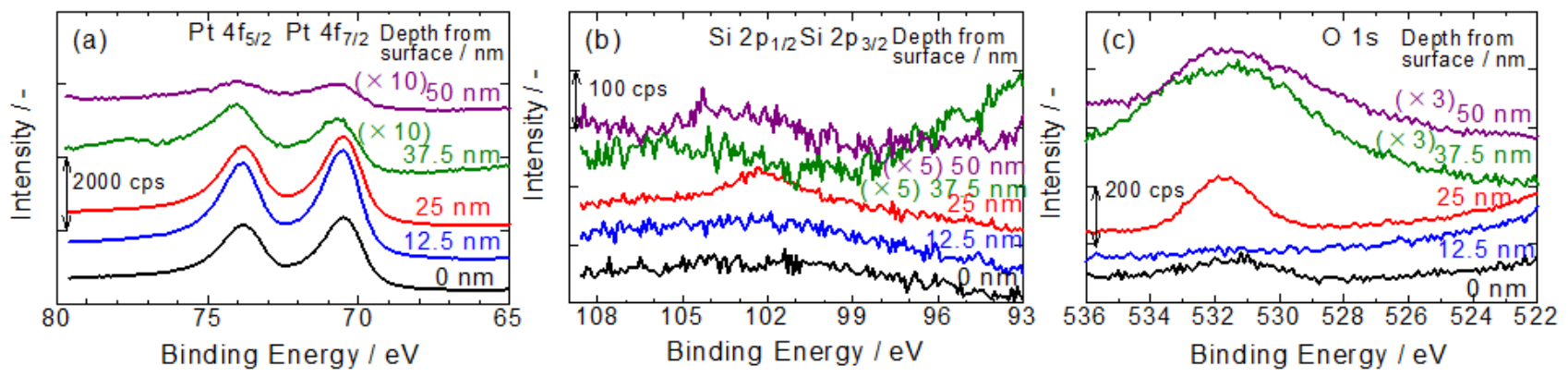

Figure S1. Pt $4 \mathrm{f}(\mathrm{a}), \mathrm{Si} 2 \mathrm{p}(\mathrm{b})$, and O is (c) XPS spectra of PTO (50 nm) on a $\mathrm{SiO}_{2}$ substrate, the durface (etching time o min) and after etching $12.5^{-50} \mathrm{~nm}$ from the surface (etching time 5-20 min).
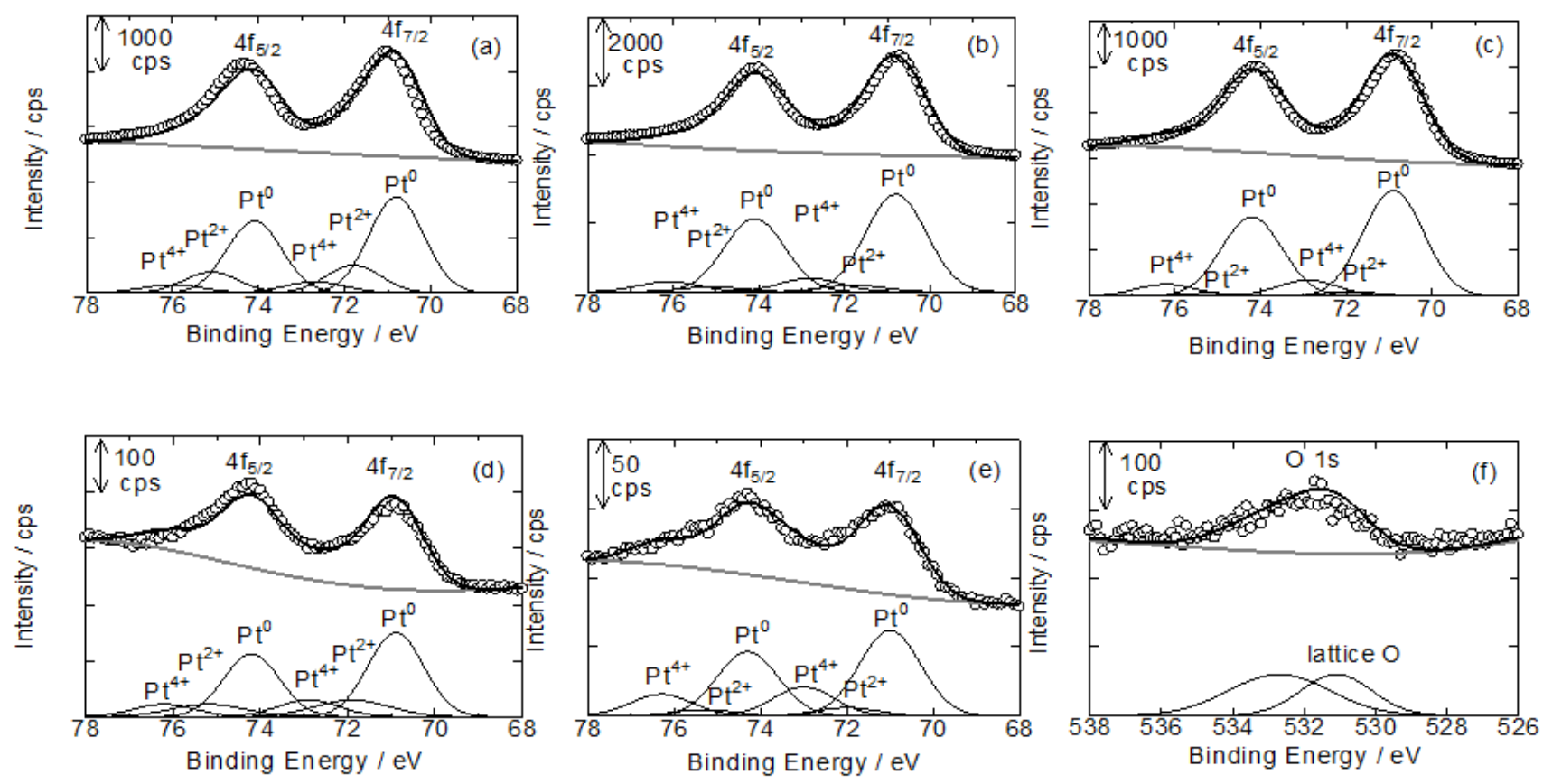

Figure S2. $\mathrm{Pt} 4 \mathrm{f}$ peak deconvolutions of PTO $(50 \mathrm{~nm})$ on a $\mathrm{SiO}_{2}$ substrate, the surface (etching time o m) (a), $12.5 \mathrm{~nm}$ from the surface (etching time $5 \mathrm{~min}$ ) (b), $25 \mathrm{~nm}$ from the surface (etching time $10 \mathrm{~min}$ ) (c), $37.5 \mathrm{~nm}$ from the surface (etching time $15 \mathrm{~min}$ ) (d), and $50 \mathrm{~nm}$ from the surface (etching time $20 \mathrm{~min}$ ) (e). $\mathrm{O}$ is peak deconvolution for the surface (etching time o min) (f). The open plots, bold black line, and bold gray line in the upper part are the experimental XPS data, fitted curve, and background, respectively. Black lines in the lower part are the deconvoluted peaks. 
Table S1. Peak deconvolution results for PTO $(50 \mathrm{~nm})$ on a $\mathrm{SiO}_{2}$ substrate. The peak positions $(\mathrm{eV})$, areas, and full widths at half maximum (FWHM, eV) for each contribution to the deconvolution, and the peak area ratios of $\mathrm{Pt} 4 \mathrm{f}_{5 / 2}$ to $\mathrm{Pt} 4 \mathrm{f}_{7 / 2}$ are shown. The deconvoluted peak area of O1s originating from lattice $\mathrm{O}$ $\left(\mathrm{O}^{2-}\right)$ on the surface is also included.

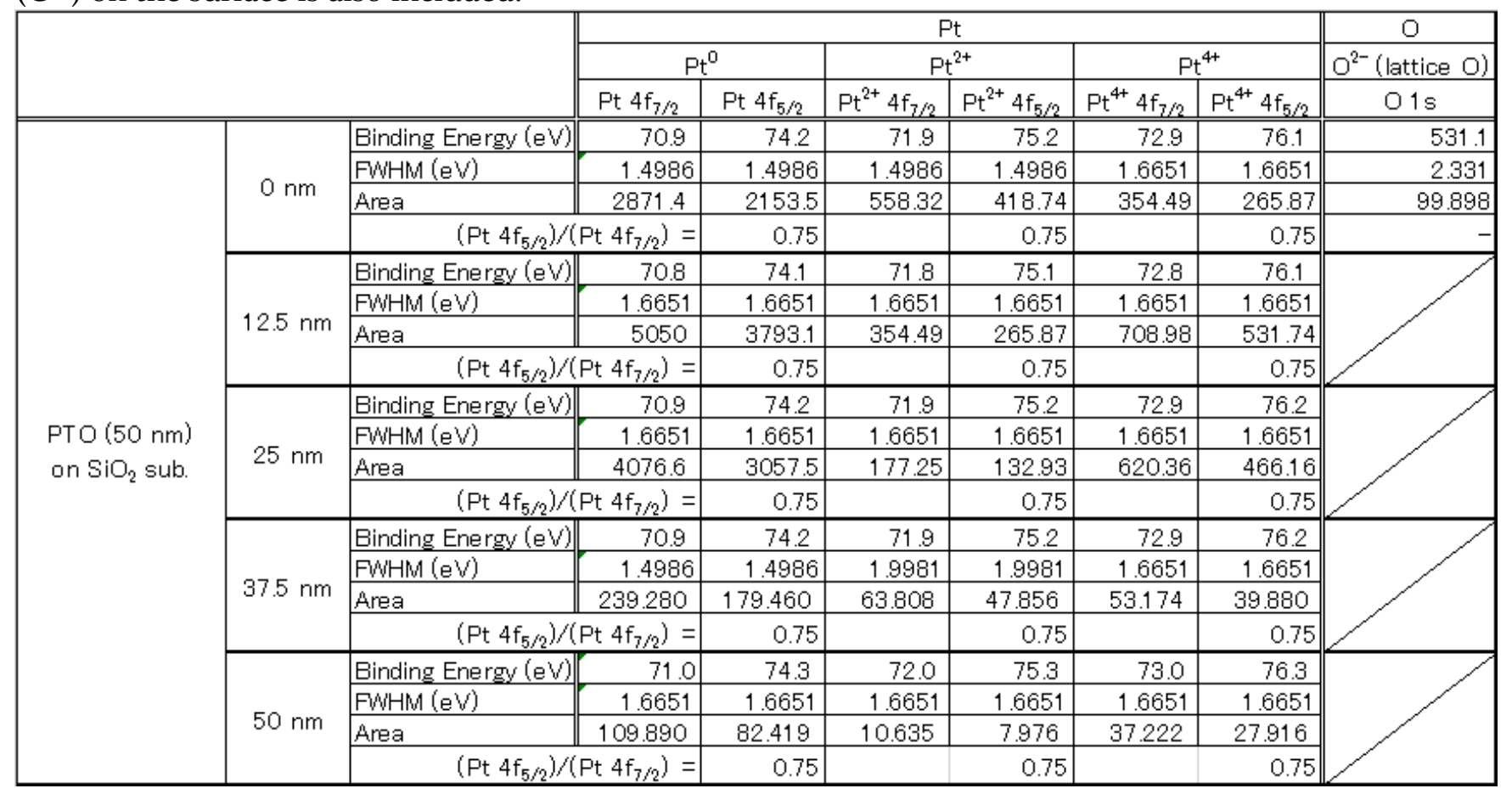

Table S2. Percentages of $\mathrm{Pt}^{\mathrm{o}}, \mathrm{Pt}^{2+}, \mathrm{Pt}^{4+}$, total $\mathrm{Pt}\left(=\mathrm{Pt}^{\mathrm{o}}+\mathrm{Pt}^{2+}+\mathrm{Pt}^{4+}\right), \mathrm{Si}$, and $\mathrm{O}$. These values were obtained from the corresponding areas in Table $\mathrm{S} 1$, which are also included.

\begin{tabular}{|c|c|c|c|c|c|c|c|c|}
\hline & & & $\mathrm{Pt}^{0}$ & $\mathrm{Pt}^{2+}$ & $\mathrm{Pt}^{4+}$ & $\begin{array}{l}\mathrm{Pt}\left(=\mathrm{Pt}^{0}+\right. \\
\left.\mathrm{Pt}^{2+}+\mathrm{Pt}^{4+}\right)\end{array}$ & $\mathrm{Si}$ & $\begin{array}{c}\mathrm{O}^{2-} \\
\text { (lattice o) }\end{array}$ \\
\hline \multirow{15}{*}{$\begin{array}{c}\mathrm{PTO}(50 \mathrm{~nm}) \\
\text { on } \mathrm{SiO}_{2} \text { sub. }\end{array}$} & \multirow{3}{*}{$0 \mathrm{~nm}$} & Area & 5024.9 & 977.1 & 620.4 & 6622.3 & 0.0 & 99.9 \\
\hline & & Composition Ratio ${ }^{* 1}$ & 901.3 & 175.3 & 111.3 & 1187.9 & 0.0 & 140.5 \\
\hline & & $\begin{array}{l}\text { Percentages of } \\
\text { each composition }\end{array}$ & 67.9 & 13.2 & 8.4 & 89.4 & 0.0 & 10.6 \\
\hline & \multirow{3}{*}{$12.5 \mathrm{~nm}$} & Area & 8843.3 & 620.4 & 1240.7 & 10704.3 & 0.0 & 0.0 \\
\hline & & Composition Ratio ${ }^{* 1}$ & 1586.2 & 111.3 & 222.6 & 1920.1 & 0.0 & 0.0 \\
\hline & & $\begin{array}{l}\text { Percentages of } \\
\text { each composition }\end{array}$ & 82.6 & 5.8 & 11.6 & 100.0 & 0.0 & 0.0 \\
\hline & \multirow{3}{*}{$25 \mathrm{~nm}$} & Area & 7134.1 & 310.2 & 1086.5 & 8530.8 & 110.6 & 488.0 \\
\hline & & Composition Ratio ${ }^{* 1}$ & 1279.7 & 55.6 & 194.9 & 1530.2 & 326.3 & 686.4 \\
\hline & & $\begin{array}{l}\text { Percentages of } \\
\text { each composition }\end{array}$ & 50.3 & 2.2 & 7.7 & 60.2 & 12.8 & 27.0 \\
\hline & \multirow{3}{*}{$37.5 \mathrm{~nm}$} & Area & 418.7 & 111.7 & 93.1 & 623.5 & 54.9 & 539.7 \\
\hline & & Composition Ratio ${ }^{* 1}$ & 75.1 & 20.0 & 16.7 & 111.8 & 162.1 & 759.0 \\
\hline & & $\begin{array}{l}\text { Percentages of } \\
\text { each composition }\end{array}$ & 7.3 & 1.9 & 1.6 & 10.8 & 15.7 & 73.5 \\
\hline & \multirow{3}{*}{$50 \mathrm{~nm}$} & Area & 192.3 & 18.6 & 65.1 & 276.1 & 74.4 & 550.8 \\
\hline & & Composition Ratio ${ }^{* 1}$ & 34.5 & 3.3 & 11.7 & 49.5 & 219.6 & 774.7 \\
\hline & & $\begin{array}{l}\text { Percentages of } \\
\text { each composition }\end{array}$ & 3.3 & 0.3 & 1.1 & 4.7 & 21.0 & 74.2 \\
\hline
\end{tabular}

${ }^{*}$ Composition ratio was obtained by dividing the area by the corresponding sensitivity factor, $\mathrm{Pt}=5 \cdot 575$, $\mathrm{Si}=0.339$, and $\mathrm{O}=0.711$. 

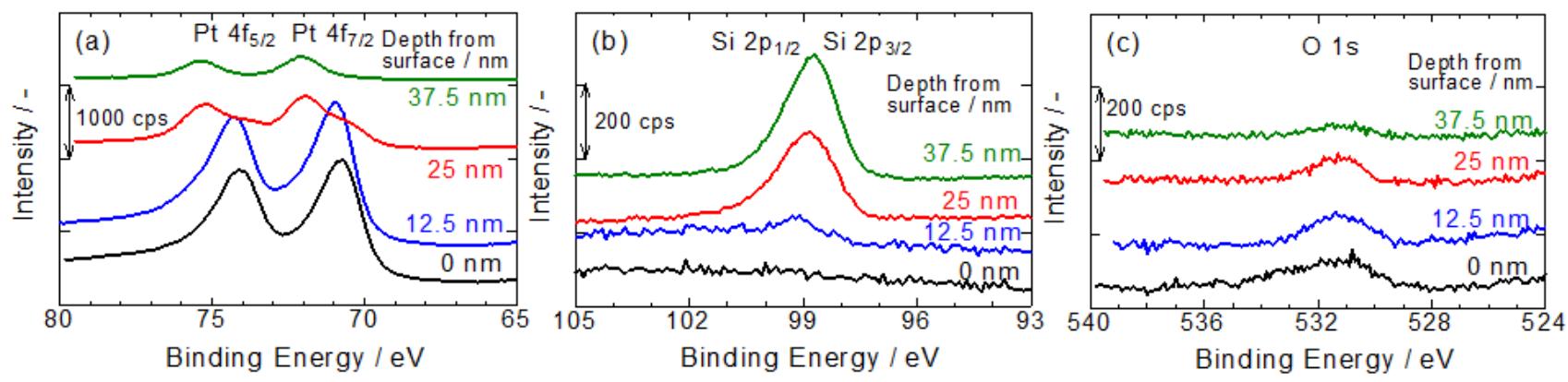

Figure S3. Pt 4f (a), Si 2p (b), and O is (c) XPS spectra of PTO (40 nm) on a Si substrate, the surface (etching time o min) and after etching $12.5^{-37.5} \mathrm{~nm}$ from the surface (etching time 5-15 min).
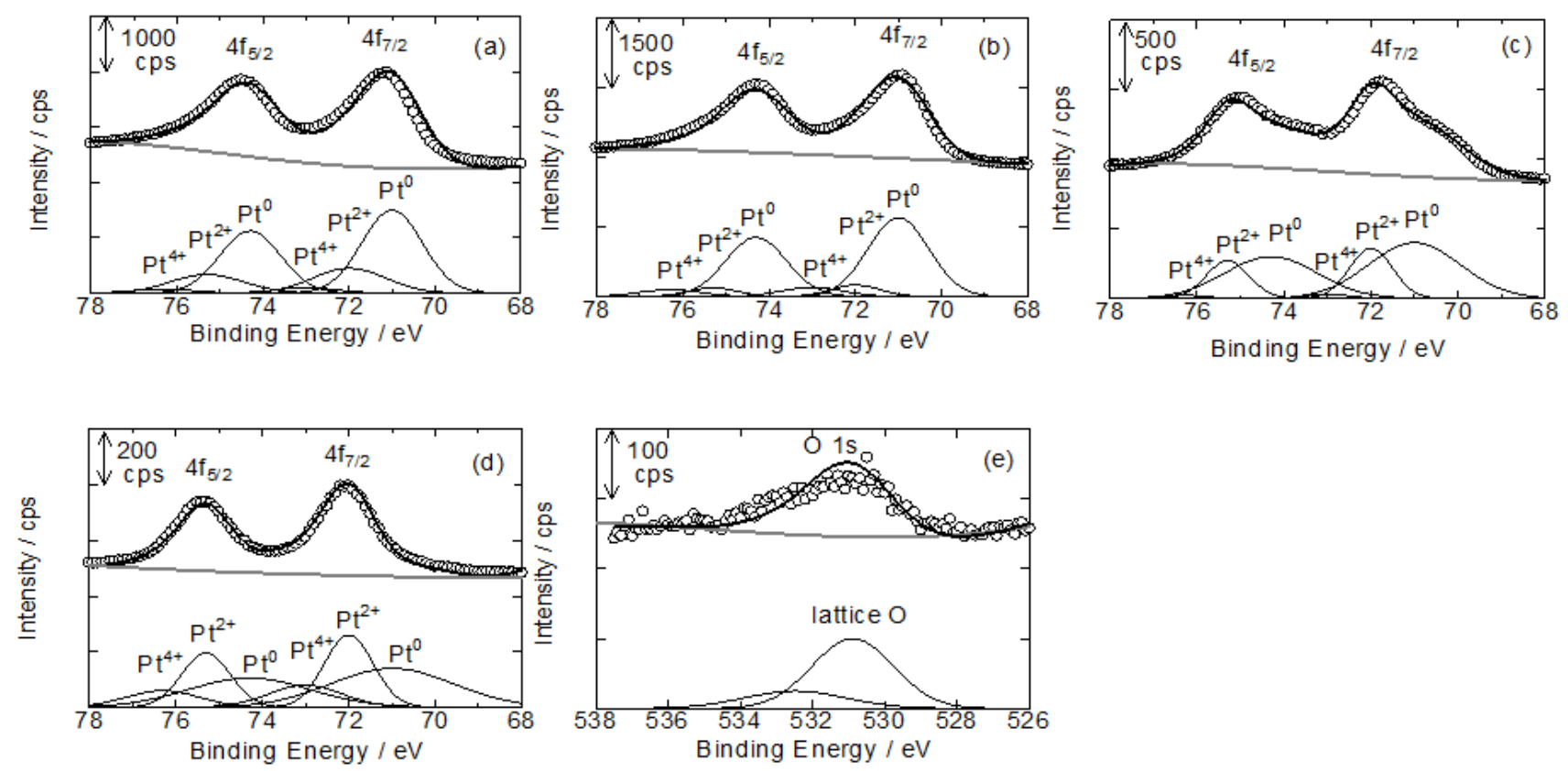

Figure S4. Pt $4 \mathrm{f}$ peak deconvolutions of PTO $(40 \mathrm{~nm})$ on a $\mathrm{Si}$ substrate for the surface (etching time o min) (a), $12.5 \mathrm{~nm}$ from the surface (etching time $5 \mathrm{~min}$ ) (b), $25 \mathrm{~nm}$ from the surface (etching time $10 \mathrm{~min}$ ) (c), and $37.5 \mathrm{~nm}$ from the surface (etching time $15 \mathrm{~min}$ ) (d). $\mathrm{O}$ is peak deconvolution for the surface (etching time o min) (e). The open plots, bold black line, and bold gray line in the upper part are the experimental XPS data, fitted curve, and background, respectively. Black lines in the lower part are the deconvoluted peaks. 
Table S3. Peak deconvolution results for PTO $(40 \mathrm{~nm})$ on a Si substrate. The peak positions $(\mathrm{eV})$, areas, and full widths at half maximum (FWHM, eV) for each contribution to the deconvolution, and the peak area ratios of $\mathrm{Pt} 4 \mathrm{f}_{5 / 2}$ to $\mathrm{Pt} 4 \mathrm{f}_{7 / 2}$ are shown. The deconvoluted peak area of Ors originating from lattice $\mathrm{O}$ $\left(\mathrm{O}^{2-}\right)$ on the surface is also included.

\begin{tabular}{|c|c|c|c|c|c|c|c|c|c|}
\hline & & & \multicolumn{6}{|c|}{$\mathrm{Pt}$} & \multirow{2}{*}{$\begin{array}{c}\mathrm{O} \\
\mathrm{O}^{2-}(\text { lattice } \mathrm{O})\end{array}$} \\
\hline & & & \multicolumn{2}{|c|}{$\mathrm{Pt}^{0}$} & \multicolumn{2}{|c|}{$\mathrm{Pt}^{2+}$} & \multicolumn{2}{|c|}{$\mathrm{Pt}^{4+}$} & \\
\hline & & & Pt $4 f_{7 / 2}$ & Pt $4 f_{5 / 2}$ & $\mathrm{Pt}^{2+} 4 \mathrm{f}_{7 / 2}$ & $\mathrm{Pt}^{2+} 4 \mathrm{f}_{5 / 2}$ & $\mathrm{Pt}^{4+} 4 \mathrm{f}_{7 / 2}$ & $\mathrm{Pt}^{4+} 4 \mathrm{f}_{5 / 2}$ & $01 \mathrm{~s}$ \\
\hline \multirow{16}{*}{$\begin{array}{c}\text { PTO (40 nm) } \\
\text { on Si sub. }\end{array}$} & \multirow{4}{*}{$0 \mathrm{~nm}$} & Binding Energy (eV) & 71.0 & 74.3 & 72.0 & 75.3 & 73.0 & 76.3 & 531 \\
\hline & & FWHM (eV) & 1.6651 & 1.6651 & 1.9981 & 1.9981 & 1.6651 & 1.6651 & 2.6642 \\
\hline & & Area & 2658.7 & 1994 & 957.13 & 717.84 & 177.25 & 132.93 & 143.77 \\
\hline & & \multicolumn{2}{|c|}{$(\mathrm{Pt} 4 f 5 / 2) /(\mathrm{Pt} 4 f 7 / 2)=$} & 0.75 & & 0.75 & & 0.75 & 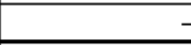 \\
\hline & \multirow{4}{*}{$12.5 \mathrm{~nm}$} & Binding Energy (eV) & 71.0 & 74.3 & 72.0 & 75.3 & 73.0 & 76.3 & \\
\hline & & FWHM (eV) & 1.6651 & 1.6651 & 1.3321 & 1.3321 & 1.6651 & 1.6651 & \\
\hline & & Area & 3013 & 2259.9 & 354.49 & 265.87 & 354.49 & 265.87 & \\
\hline & & \multicolumn{2}{|c|}{$(\mathrm{Pt} 455 / 2) /(\mathrm{Pt} 47 / / 2)=$} & 0.75 & & 0.75 & & 0.75 & \\
\hline & \multirow{4}{*}{$25 \mathrm{~nm}$} & Binding Energy (eV) & 71.0 & 74.3 & 72.0 & 75.3 & 73.0 & 76.3 & \\
\hline & & FWHM (eV) & 2.4977 & 2.4977 & 1.1656 & 1.1656 & 1.1656 & 1.1656 & \\
\hline & & Area & 1063.5 & 797.6 & 446.66 & 334.99 & 37.222 & 27.916 & \\
\hline & & $(\mathrm{Pt} 4+5 / 2) /(\mathrm{P}$ & $4 f 7 / 2)=$ & 0.75 & & 0.75 & & 0.75 & \\
\hline & \multirow{4}{*}{$37.5 \mathrm{~nm}$} & Binding Energy (eV) & 71.0 & 74.3 & 72.0 & 75.3 & 73.0 & 76.3 & \\
\hline & & FWHM (eV) & 3.3302 & 3.3302 & 1.6651 & 1.6651 & 1.9981 & 1.9981 & \\
\hline & & Area & 425.390 & 319.040 & 584.910 & 438.680 & 95.713 & 71.784 & \\
\hline & & $(\mathrm{Pt} 4 \mathrm{f5} / 2) /(\mathrm{P}$ & $4 f 7 / 2)=$ & 0.75 & & 0.75 & & 0.75 & \\
\hline
\end{tabular}

Table S4. Percentages of $\mathrm{Pt}^{\mathrm{o}}, \mathrm{Pt}^{2+}, \mathrm{Pt}^{4+}$, total $\mathrm{Pt}\left(=\mathrm{Pt}^{\mathrm{o}}+\mathrm{Pt}^{2+}+\mathrm{Pt}^{4+}\right), \mathrm{Si}$, and $\mathrm{O}$. These values were obtained from the corresponding areas in Table $S_{3}$, which are also included.

\begin{tabular}{|c|c|c|c|c|c|c|c|c|}
\hline & & & $\mathrm{Pt}^{0}$ & $\mathrm{Pt}^{2+}$ & $\mathrm{Pt}^{4+}$ & $\begin{array}{l}\mathrm{Pt}\left(=\mathrm{Pt}^{0}+\right. \\
\left.\mathrm{Pt}^{2+}+\mathrm{Pt}^{4+}\right)\end{array}$ & $\mathrm{Si}$ & $\begin{array}{c}\mathrm{O}^{2-} \\
\text { (lattice }\end{array}$ \\
\hline \multirow{12}{*}{$\begin{array}{l}\text { PTO (40 nm) } \\
\text { on Si sub. }\end{array}$} & \multirow{3}{*}{$0 \mathrm{~nm}$} & Area & 4652.7 & 1675.0 & 310.2 & 6637.9 & 0.0 & 143.8 \\
\hline & & Composition Ratio ${ }^{* 1}$ & 834.6 & 300.4 & 55.6 & 1190.6 & 0.0 & 202.2 \\
\hline & & $\begin{array}{l}\text { Percentages of } \\
\text { each composition }\end{array}$ & 59.9 & 21.6 & 4.0 & 85.5 & 0.0 & 14.5 \\
\hline & \multirow{3}{*}{$12.5 \mathrm{~nm}$} & Area & 5273.1 & 620.4 & 620.4 & 6513.8 & 76.7 & 116.6 \\
\hline & & Composition Ratio ${ }^{* 1}$ & 945.8 & 111.3 & 111.3 & 1168.4 & 226.2 & 164.1 \\
\hline & & $\begin{array}{l}\text { Percentages of } \\
\text { each composition }\end{array}$ & 60.7 & 7.1 & 7.1 & 75.0 & 14.5 & 10.5 \\
\hline & \multirow{3}{*}{$25 \mathrm{~nm}$} & Area & 1861.1 & 781.7 & 65.1 & 2707.9 & 425.8 & 101.8 \\
\hline & & Composition Ratio ${ }^{* 1}$ & 333.8 & 140.2 & 11.7 & 485.7 & 1256.0 & 143.2 \\
\hline & & $\begin{array}{l}\text { Percentages of } \\
\text { each composition }\end{array}$ & 17.7 & 7.4 & 0.6 & 25.8 & 66.6 & 7.6 \\
\hline & \multirow{3}{*}{$37.5 \mathrm{~nm}$} & Area & 744.4 & 1023.6 & 167.5 & 1935.5 & 565.9 & 82.5 \\
\hline & & Composition Ratio ${ }^{* 1}$ & 133.5 & 183.6 & 30.0 & 347.2 & 1669.3 & 116.0 \\
\hline & & $\begin{array}{l}\text { Percentages of } \\
\text { each composition }\end{array}$ & 6.3 & 8.6 & 1.4 & 16.3 & 78.3 & 5.4 \\
\hline
\end{tabular}

${ }^{{ }^{*}}$ Composition ratio was obtained by dividing the area by the corresponding sensitivity factor, $\mathrm{Pt}=5 \cdot 575$, $\mathrm{Si}=0.339$, and $\mathrm{O}=0.711$. 

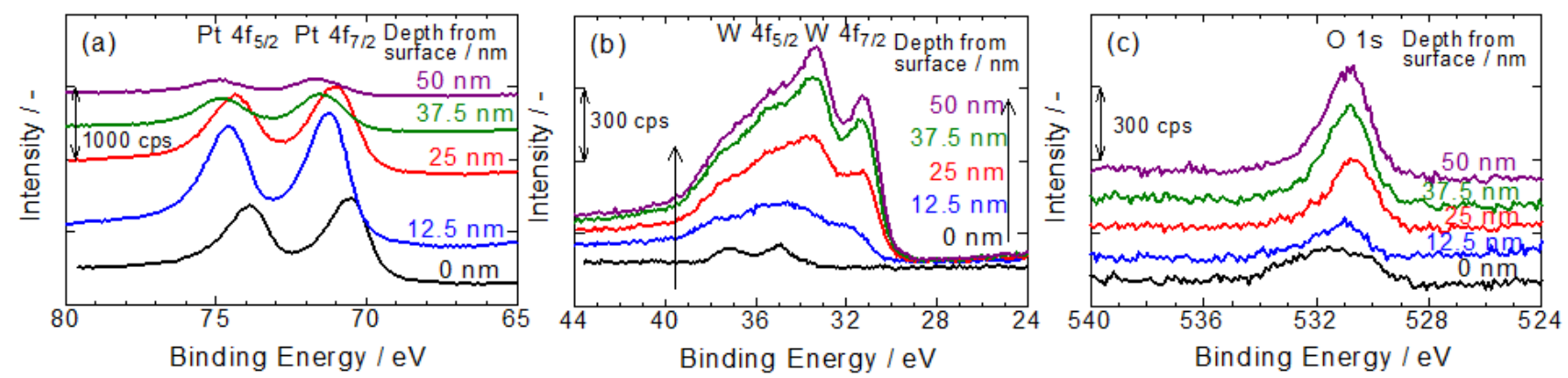

Figure $\mathrm{S}_{5}$. Pt $4 \mathrm{f}(\mathrm{a}), \mathrm{Si} 2 \mathrm{p}(\mathrm{b})$, and $\mathrm{O}$ is (c) XPS spectra of PTO $(50 \mathrm{~nm}) / \mathrm{WO}_{3}$ on a $\mathrm{SiO}_{2}$ substrate, the surface (etching time $\mathrm{o} \mathrm{min}$ ) and after etching $12.5^{-50} \mathrm{~nm}$ from the surface (etching time 5-20 $\mathrm{min}$ ).
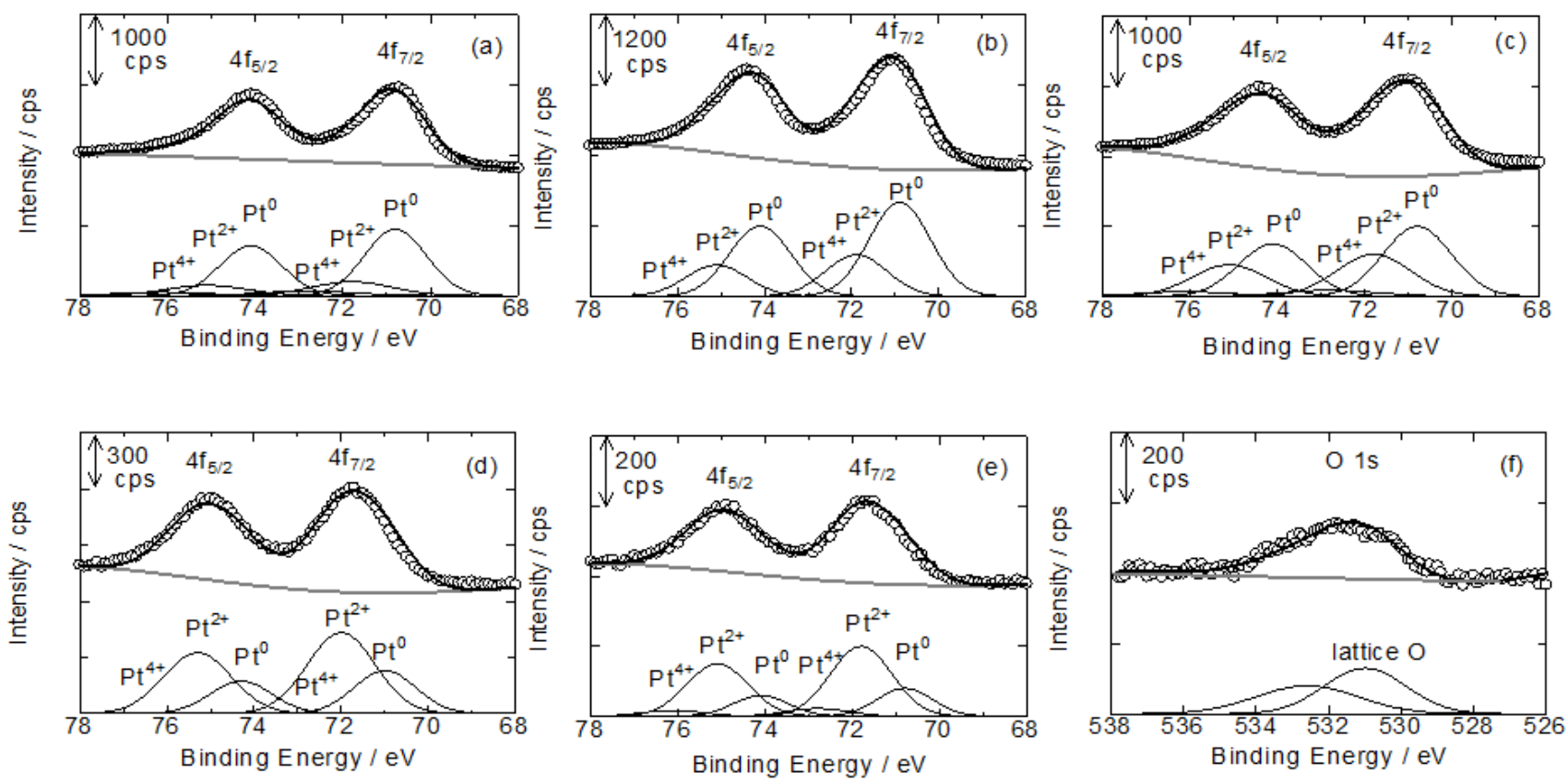

Figure S6. $\mathrm{Pt} 4 \mathrm{f}$ peak deconvolutions of PTO $(50 \mathrm{~nm}) / \mathrm{WO}_{3}$ on a $\mathrm{SiO}_{2}$ substrate for the surface (etching time o $\mathrm{min}$ ) (a), $12.5 \mathrm{~nm}$ from the surface (etching time $5 \mathrm{~min}$ ) (b), $25 \mathrm{~nm}$ from the surface (etching time $10 \mathrm{~min}$ ) (c), $37.5 \mathrm{~nm}$ from the surface (etching time $15 \mathrm{~min}$ ) (d), and $50 \mathrm{~nm}$ from the surface (etching time $20 \mathrm{~min}$ ) (e). $\mathrm{O}$ is peak deconvolution for the surface (etching time o min) (f). The open plots, bold black line, and bold gray line in the upper part are the experimental XPS data, fitted curve, and background, respectively. Black lines in the lower part are the deconvoluted peaks. 
Table S5. Peak deconvolution results for PTO $(50 \mathrm{~nm}) / \mathrm{WO}_{3}$ on a Si substrate. The peak positions $(\mathrm{eV})$, areas, and full widths at half maximum (FWHM, eV) for each contribution to the deconvolution, and the peak area ratios of $\mathrm{Pt} 4 \mathrm{f}_{5 / 2}$ to $\mathrm{Pt} 4 \mathrm{f}_{7 / 2}$ are shown. The deconvoluted peak area of Ois originating from lattice $\mathrm{O}\left(\mathrm{O}^{2-}\right)$ on the surface is also included.

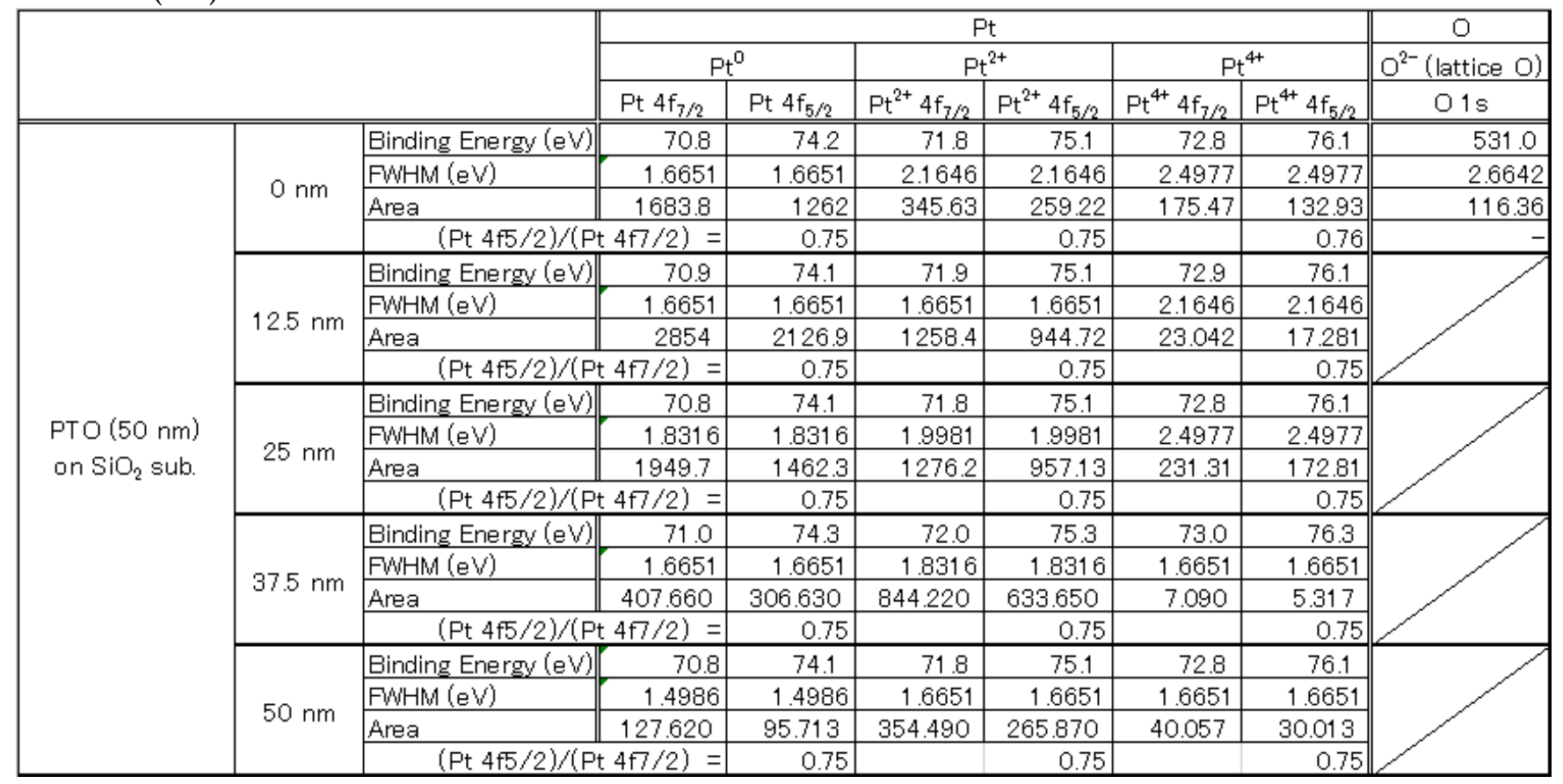

Table S6. Percentages of $\mathrm{Pt}^{\circ}, \mathrm{Pt}^{2+}, \mathrm{Pt}^{4+}$, total $\mathrm{Pt}\left(=\mathrm{Pt}^{0}+\mathrm{Pt}^{2+}+\mathrm{Pt}^{4+}\right), \mathrm{W}$, and $\mathrm{O}$. These values were obtained from the corresponding areas in Table $\mathrm{S}_{5}$, which are also included.

\begin{tabular}{|c|c|c|c|c|c|c|c|c|}
\hline & & & $\mathrm{Pt}^{0}$ & $\mathrm{Pt}^{2+}$ & $\mathrm{Pt}^{4+}$ & $\begin{array}{l}\mathrm{Pt}\left(=\mathrm{Pt}^{0}+\right. \\
\left.\mathrm{Pt}^{2+}+\mathrm{Pt}^{4+}\right)\end{array}$ & $w$ & $\begin{array}{c}\mathrm{O}^{2-} \\
\text { (lattice o) }\end{array}$ \\
\hline \multirow{15}{*}{$\begin{array}{l}\text { PTO }(50 \mathrm{~nm}) \\
\text { on } \mathrm{SiO}_{2} \text { sub. }\end{array}$} & \multirow{3}{*}{$0 \mathrm{~nm}$} & Area & 2945.8 & 604.9 & 308.4 & 3859.1 & 0.0 & 116.4 \\
\hline & & Composition Ratio ${ }^{* 1}$ & 528.4 & 108.5 & 55.3 & 692.2 & 0.0 & 163.7 \\
\hline & & $\begin{array}{l}\text { Percentages of } \\
\text { each composition }\end{array}$ & 61.7 & 12.7 & 6.5 & 80.9 & 0.0 & 19.1 \\
\hline & \multirow{3}{*}{$12.5 \mathrm{~nm}$} & Area & 4980.8 & 2203.1 & 40.3 & 7224.2 & 0.0 & 119.7 \\
\hline & & Composition Ratio ${ }^{* 1}$ & 893.4 & 395.2 & 7.2 & 1295.8 & 0.0 & 168.4 \\
\hline & & $\begin{array}{l}\text { Percentages of } \\
\text { each composition }\end{array}$ & 61.0 & 27.0 & 0.5 & 88.5 & 0.0 & 11.5 \\
\hline & \multirow{3}{*}{$25 \mathrm{~nm}$} & Area & 3412.0 & 2233.3 & 404.1 & 6049.5 & 2686.3 & 521.4 \\
\hline & & Composition Ratio ${ }^{* 1}$ & 612.0 & 400.6 & 72.5 & 1085.1 & 762.5 & 733.3 \\
\hline & & $\begin{array}{l}\text { Percentages of } \\
\text { each composition }\end{array}$ & 23.7 & 15.5 & 2.8 & 42.0 & 29.5 & 28.4 \\
\hline & \multirow{3}{*}{$37.5 \mathrm{~nm}$} & Area & 714.3 & 1477.9 & 12.4 & 2204.6 & 3681.9 & 773.6 \\
\hline & & Composition Ratio ${ }^{* 1}$ & 128.1 & 265.1 & 2.2 & 395.4 & 1045.1 & 1088.0 \\
\hline & & $\begin{array}{l}\text { Percentages of } \\
\text { each composition }\end{array}$ & 5.1 & 10.5 & 0.1 & 15.6 & 41.3 & 43.0 \\
\hline & \multirow{3}{*}{$50 \mathrm{~nm}$} & Area & 223.3 & 620.4 & 70.1 & 913.8 & 4160.7 & 879.2 \\
\hline & & Composition Ratio ${ }^{* 1}$ & 40.1 & 111.3 & 12.6 & 163.9 & 1181.0 & 1236.6 \\
\hline & & $\begin{array}{l}\text { Percentages of } \\
\text { each composition }\end{array}$ & 1.6 & 4.3 & 0.5 & 6.3 & 45.7 & 47.9 \\
\hline
\end{tabular}

${ }^{*}$ Composition ratio was obtained by dividing the area by the corresponding sensitivity factor, $\mathrm{Pt}=5.575$, $\mathrm{W}=3.523$, and $\mathrm{O}=0.711$. 

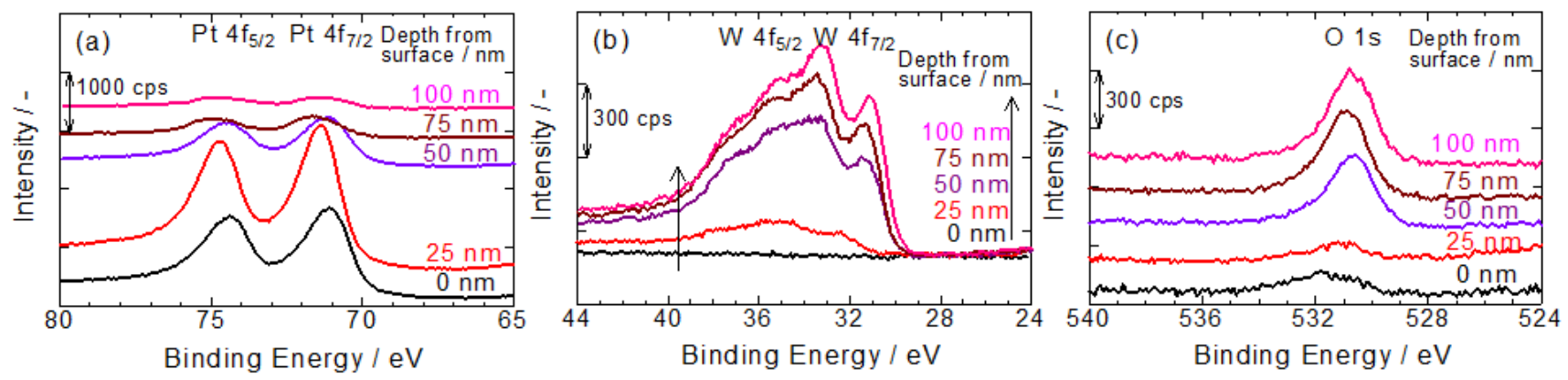

Figure $\mathrm{S}_{7}$. Pt $4 \mathrm{f}(\mathrm{a}), \mathrm{W} 4 \mathrm{f}(\mathrm{b})$, and $\mathrm{O}$ is (c) XPS spectra of PTO $(90 \mathrm{~nm}) / \mathrm{WO}_{3}$ on a $\mathrm{SiO}_{2}$ substrate, the surface (etching time o min) and after etching $25^{-100 ~} \mathrm{~nm}$ from the surface (etching time $10-40 \mathrm{~min}$ ).
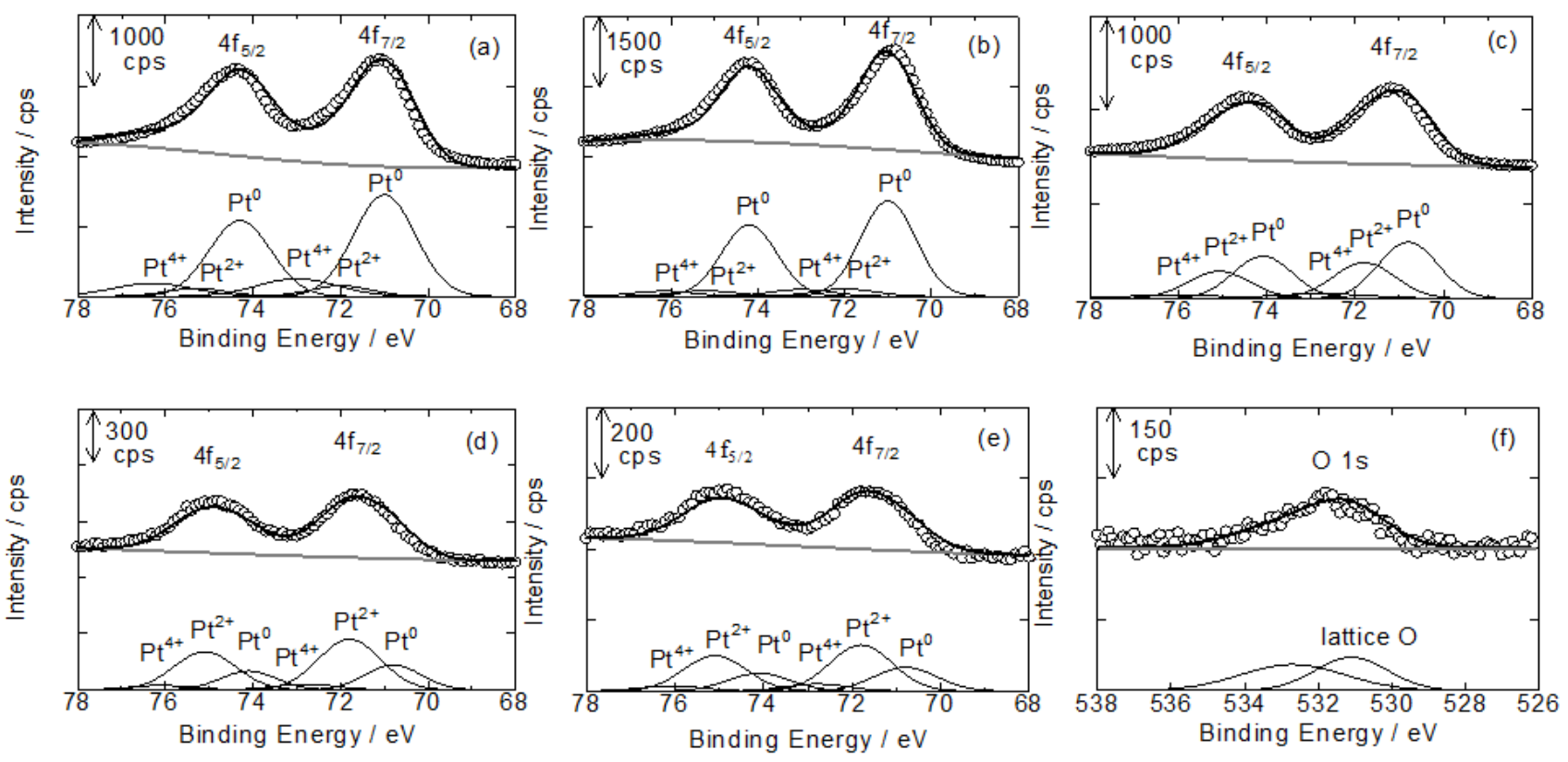

Figure S8. Pt $4 \mathrm{f}$ peak deconvolutions of $\mathrm{PTO}(90 \mathrm{~nm}) / \mathrm{WO}_{3}$ on a $\mathrm{SiO}_{2}$ substrate for the surface (etching time o min) (a), $25 \mathrm{~nm}$ from the surface (etching time $10 \mathrm{~min}$ ) (b), $50 \mathrm{~nm}$ from the surface (etching time $20 \mathrm{~min}$ ) (c), $75 \mathrm{~nm}$ from the surface (etching time $30 \mathrm{~min}$ ) (d), and $100 \mathrm{~nm}$ from the surface (etching time $40 \mathrm{~min}$ ) (e). O is peak deconvolution for the surface (etching time o min) (f). The open plots, bold black line, and bold gray line in the upper part are the experimental XPS data, fitted curve, and background, respectively. Black lines in the lower part are the deconvoluted peaks. 
Table S7. Peak deconvolution results for PTO $(90 \mathrm{~nm}) / \mathrm{WO}_{3}$ on a Si substrate. The peak positions $(\mathrm{eV})$, areas, and full widths at half maximum (FWHM, eV) for each contribution to the deconvolution, and the peak area ratios of $\mathrm{Pt} 4 \mathrm{f}_{5 / 2}$ to $\mathrm{Pt} 4 \mathrm{f}_{7 / 2}$ are shown. The deconvoluted peak area of O1s originating from lattice $\mathrm{O}\left(\mathrm{O}^{2-}\right)$ on the surface is also included.

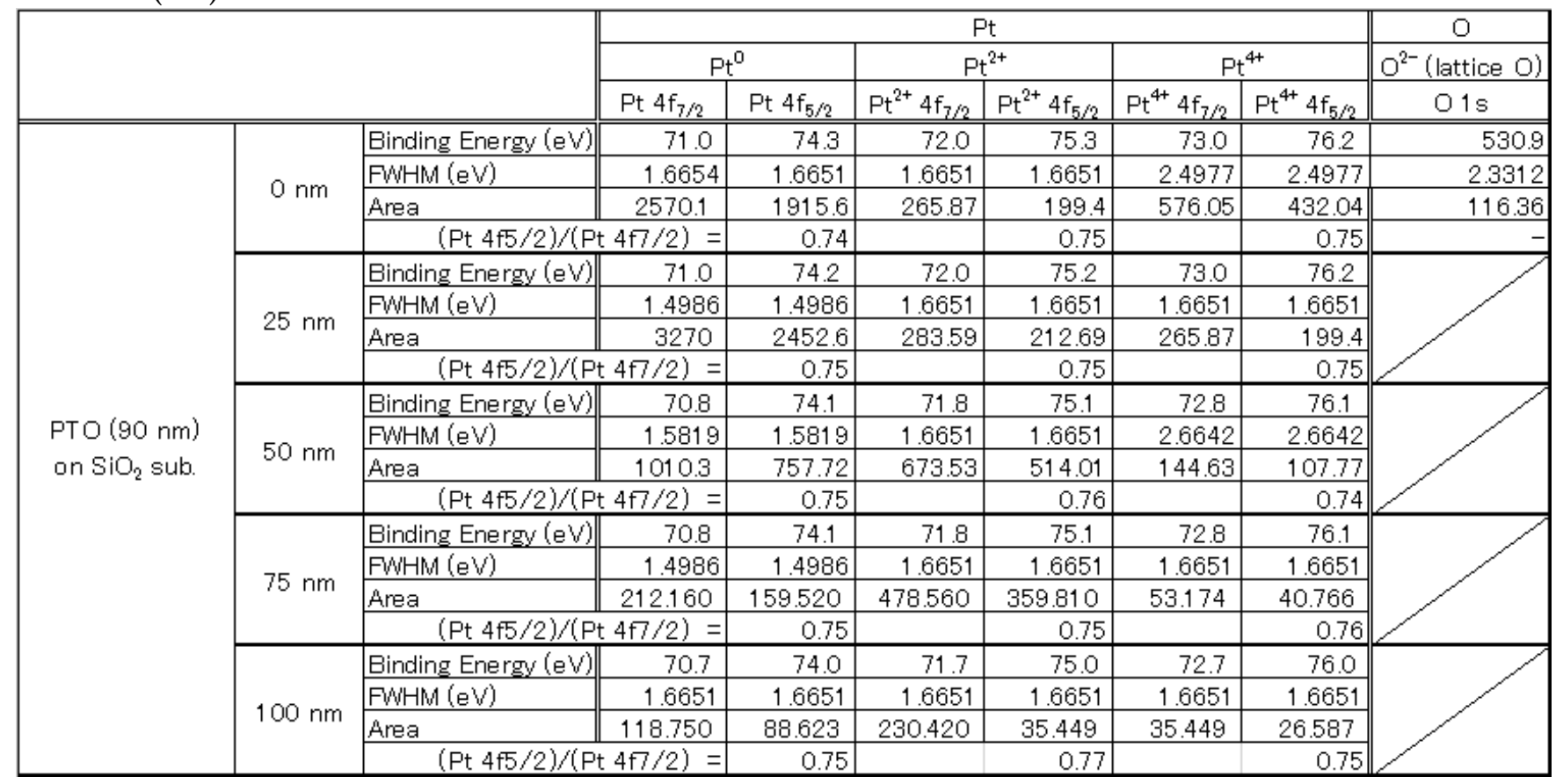

Table S8. Percentages of $\mathrm{Pt}^{\circ}, \mathrm{Pt}^{2+}, \mathrm{Pt}^{4+}$, total $\mathrm{Pt}\left(=\mathrm{Pt}^{0}+\mathrm{Pt}^{2+}+\mathrm{Pt}^{4+}\right), \mathrm{W}$, and $\mathrm{O}$. These values were obtained from the corresponding areas in Table $\mathrm{S}_{7}$, which are also included.

\begin{tabular}{|c|c|c|c|c|c|c|c|c|}
\hline & & & $\mathrm{Pt}^{0}$ & $\mathrm{Pt}^{2+}$ & $\mathrm{Pt}^{4+}$ & $\begin{array}{l}\mathrm{Pt}\left(=\mathrm{Pt}^{0}+\right. \\
\left.\mathrm{Pt}^{2+}+\mathrm{Pt}^{4+}\right)\end{array}$ & $w$ & $\begin{array}{c}\mathrm{O}^{2-} \\
\text { (lattice o) }\end{array}$ \\
\hline \multirow{15}{*}{$\begin{array}{l}\text { PTO }(90 \mathrm{~nm}) \\
\text { on } \mathrm{SiO}_{2} \text { sub. }\end{array}$} & \multirow{3}{*}{$0 \mathrm{~nm}$} & Area & 44485.7 & 4655.3 & 1008.1 & 5959.1 & 0.0 & 103.5 \\
\hline & & Composition Ratio ${ }^{* 1}$ & 804.6 & 83.5 & 180.8 & 1068.9 & 0.0 & 145.6 \\
\hline & & $\begin{array}{l}\text { Percentages of } \\
\text { each composition }\end{array}$ & 66.3 & 6.9 & 14.9 & 88.0 & 0.0 & 12.0 \\
\hline & \multirow{3}{*}{$25 \mathrm{~nm}$} & Area & 5722.8 & 496.3 & 465.3 & 6684.4 & 0.0 & 196.8 \\
\hline & & Composition Ratio ${ }^{* 1}$ & 1026.5 & 89.0 & 83.5 & 1199.0 & 0.0 & 276.8 \\
\hline & & $\begin{array}{l}\text { Percentages of } \\
\text { each composition }\end{array}$ & 69.6 & 6.0 & 5.7 & 81.2 & 0.0 & 18.8 \\
\hline & \multirow{3}{*}{$50 \mathrm{~nm}$} & Area & 1768.0 & 1187.5 & 252.4 & 3208.0 & 2699.8 & 684.2 \\
\hline & & Composition Ratio ${ }^{* 1}$ & 317.1 & 213.0 & 45.3 & 575.4 & 766.3 & 962.3 \\
\hline & & $\begin{array}{l}\text { Percentages of } \\
\text { each composition }\end{array}$ & 13.8 & 9.2 & 2.0 & 25.0 & 33.3 & 41.8 \\
\hline & \multirow{3}{*}{$75 \mathrm{~nm}$} & Area & 371.7 & 838.4 & 93.9 & 1304.0 & 3294.7 & 850.4 \\
\hline & & Composition Ratio ${ }^{* 1}$ & 66.7 & 150.4 & 16.9 & 233.9 & 935.2 & 1196.0 \\
\hline & & $\begin{array}{l}\text { Percentages of } \\
\text { each composition }\end{array}$ & 2.8 & 6.4 & 0.7 & 9.9 & 39.5 & 50.6 \\
\hline & \multirow{3}{*}{$100 \mathrm{~nm}$} & Area & 207.4 & 265.9 & 62.0 & 535.3 & 4139.1 & 905.4 \\
\hline & & Composition Ratio ${ }^{* 1}$ & 37.2 & 47.7 & 11.1 & 96.0 & 1174.9 & 1273.4 \\
\hline & & $\begin{array}{l}\text { Percentages of } \\
\text { each composition }\end{array}$ & 1.5 & 1.9 & 0.4 & 3.8 & 46.2 & 50.0 \\
\hline
\end{tabular}

${ }^{*}$ Composition ratio was obtained by dividing the area by the corresponding sensitivity factor, $\mathrm{Pt}=5.575$, $\mathrm{W}=3.523$, and $\mathrm{O}=0.711$. 
S. I. 2) Detailed explanation of process for obtaining numbers of absorbed photons (Figure S9, Table S9)

In Fig. S9, UV-visible absorption spectra of PTO (50 nm), PTO (9o nm), PTO (50 nm)/ $\mathrm{H}_{y} \mathrm{WO}_{3}$, and PTO $(90 \mathrm{~nm}) / \mathrm{H}_{\mathrm{y}} \mathrm{WO}_{3}$ are shown, including the spectrum of irradiated light. We calculated the number of absorbed photons for PTO $(50 \mathrm{~nm}, 90 \mathrm{~nm})$ and $\mathrm{H}_{y} \mathrm{WO}_{3}$ in PTO $(50 \mathrm{~nm}) / \mathrm{H}_{y} \mathrm{WO}_{3}$ and PTO (9o $\mathrm{nm}) / \mathrm{H}_{y} \mathrm{WO}_{3}$ using the following summation with $1 \mathrm{~nm}$ steps of $\lambda$, where the irradiation area was $1.0 \mathrm{~cm}^{2}$.

$$
\sum_{\lambda=300}^{800}\left[\frac{(100-\text { Reflectance) }}{100} \times \frac{(\text { Light intensity) } \times 1.0}{\text { Energy }}\right]_{\lambda} \quad \text { (quanta/s) }
$$

Then, the number of absorbed photons for $\mathrm{H}_{y} \mathrm{WO}_{3}$ in $\mathrm{PTO}(50 \mathrm{~nm}) / \mathrm{H}_{y} \mathrm{WO}_{3}$ was calculated by subtracting that for PTO $(50 \mathrm{~nm})$ from that for PTO $(50 \mathrm{~nm}) / \mathrm{H}_{y} \mathrm{WO}_{3}$. Similarly, the number of absorbed photons for $\mathrm{H}_{y} \mathrm{WO}_{3}$ in $\mathrm{PTO}(90 \mathrm{~nm}) / \mathrm{H}_{y} \mathrm{WO}_{3}$ was obtained and is summarized in Table S9.

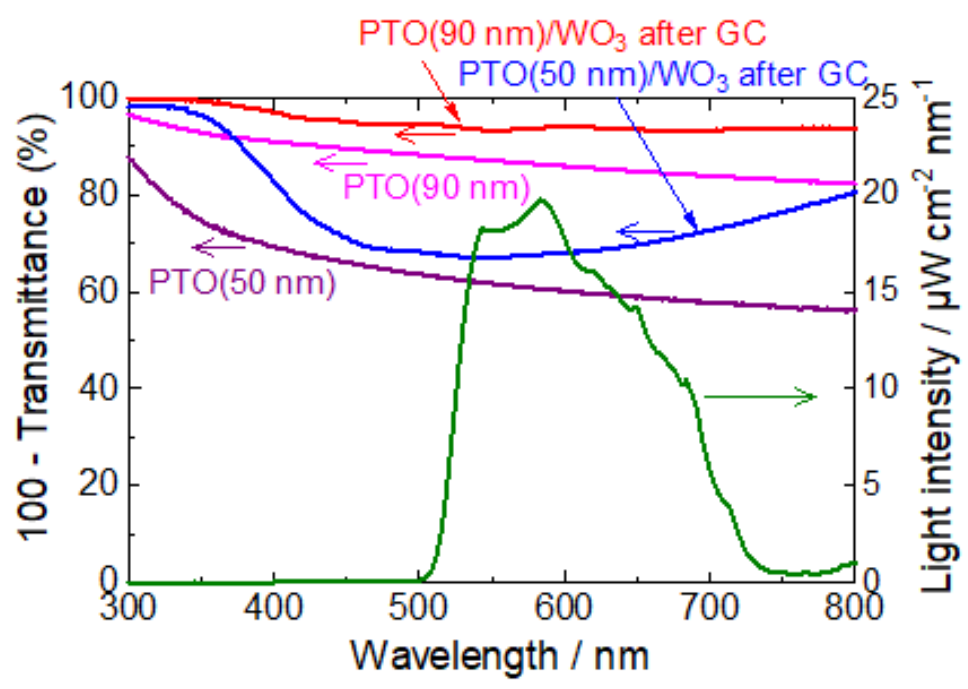

Figure S9. UV-visible absorption spectra of PTO (50 nm), PTO (9o nm), PTO $(50 \mathrm{~nm}) / \mathrm{H}_{y} \mathrm{WO}_{3}$, and PTO $(90 \mathrm{~nm}) / \mathrm{H}_{y} \mathrm{WO}_{3}$. The wavelength distribution of the irradiated light is also included.

Table S9. Calculated number of absorbed photons for PTO (50, $90 \mathrm{~nm}) / \mathrm{H}_{y} \mathrm{WO}_{3}$, PTO (50, $90 \mathrm{~nm}$ ), and $\mathrm{H}_{\mathrm{y}} \mathrm{WO}_{3}$ in $\mathrm{PTO}(50,90 \mathrm{~nm}) / \mathrm{H}_{\mathrm{y}} \mathrm{WO}_{3}$.

\begin{tabular}{l|c|c|c}
\hline & \multicolumn{3}{|c}{ Absorbed photon number / quanta s } \\
\cline { 2 - 4 } & $\mathrm{PTO} / \mathrm{H}_{y} \mathrm{WO}_{3}$ & $\mathrm{PTO}$ & $\mathrm{H}_{y} \mathrm{WO}_{3}$ \\
\hline \hline PTO $(50 \mathrm{~nm}) / \mathrm{H}_{y} \mathrm{WO}_{3}$ & $1.7 \times 10^{16}$ & $1.5 \times 10^{16}$ & $2.2 \times 10^{15}$ \\
\hline $\mathrm{PTO}(90 \mathrm{~nm}) / \mathrm{H}_{y} \mathrm{WO}_{3}$ & $2.3 \times 10^{16}$ & $2.1 \times 10^{16}$ & $2.0 \times 10^{15}$ \\
\hline
\end{tabular}



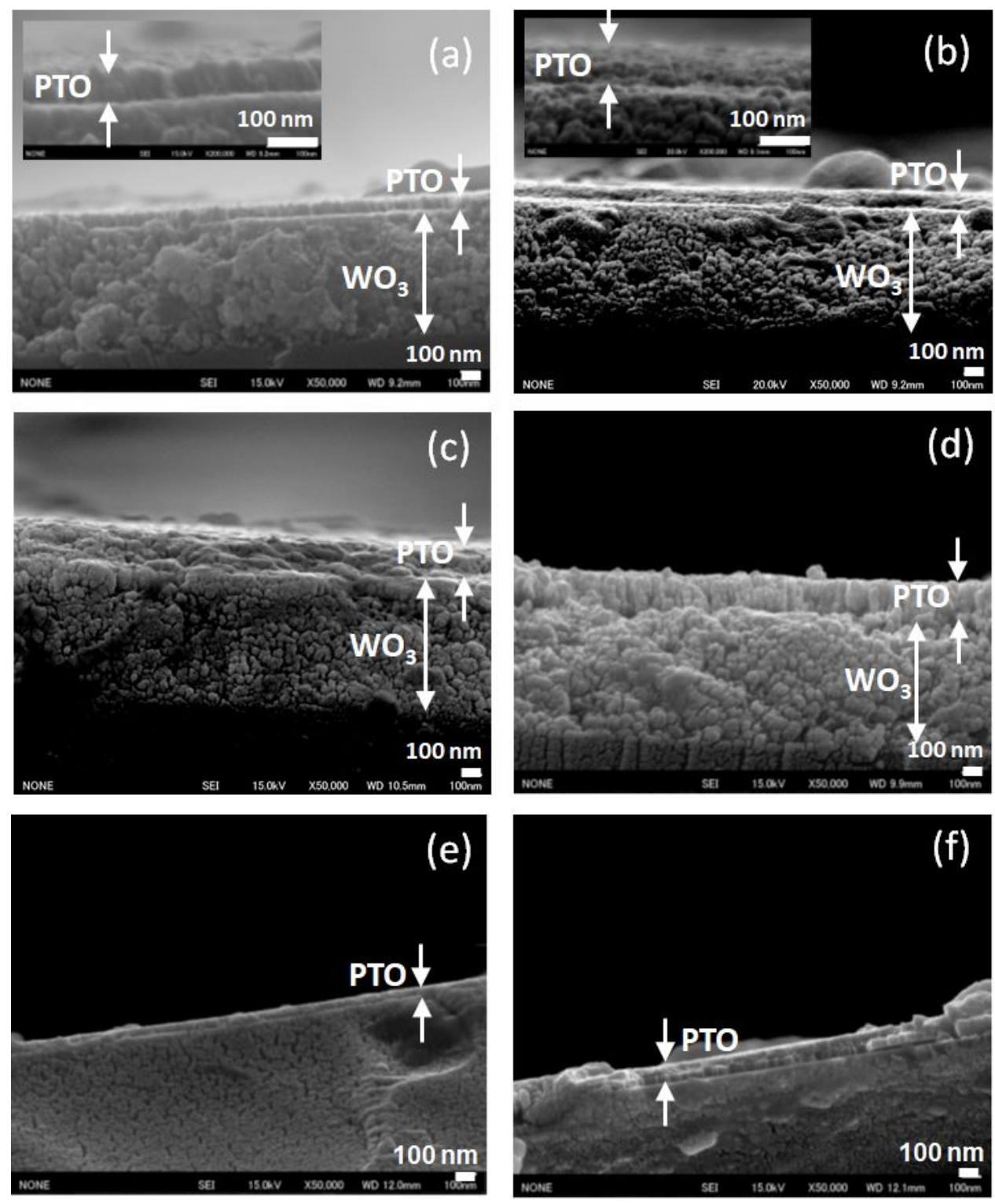

Figure S1o. Cross-sectional SEM images of PTO $(50 \mathrm{~nm}) / \mathrm{WO}_{3}(650 \mathrm{~nm})(\mathrm{a}), \mathrm{PTO}(90 \mathrm{~nm}) / \mathrm{WO}_{3}(650$ $\mathrm{nm})(\mathrm{b})$, PTO $(200 \mathrm{~nm}) / \mathrm{WO}_{3}(650 \mathrm{~nm})(\mathrm{c})$, PTO $(250 \mathrm{~nm}) / \mathrm{WO}_{3}(650 \mathrm{~nm})(\mathrm{d}), \mathrm{PTO}(40 \mathrm{~nm})$ on Si (e), and PTO (5o nm) on $\mathrm{SiO}_{2}(\mathrm{f})$. 

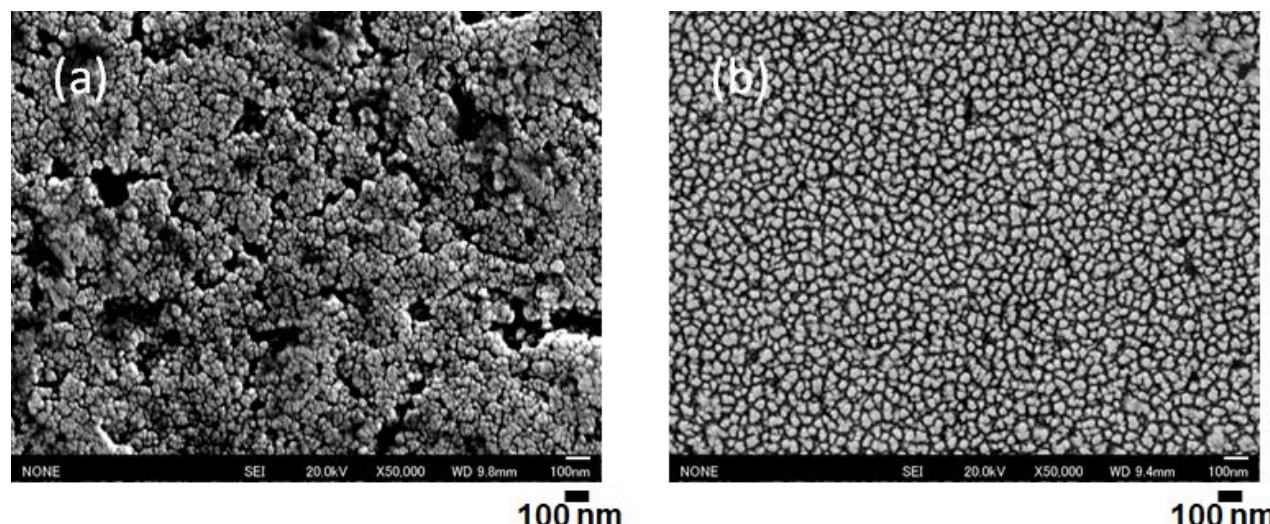

Figure S11. Surface SEM images of PTO $(50 \mathrm{~nm}) / \mathrm{WO}_{3}(650 \mathrm{~nm})(\mathrm{a})$ and PTO $(90 \mathrm{~nm}) / \mathrm{WO}_{3}(650 \mathrm{~nm})(\mathrm{b})$. 


\section{S. I. 4) Schematic diagram of $\mathrm{PTO} / \mathrm{WO}_{3}, \mathrm{H}_{y} \mathrm{WO}_{3}$ (Figure $\mathrm{S} 12$ )}

The band edge position and the bandgap of $\mathrm{WO}_{3}$ are well-known. ${ }^{36}$, a In contrast, those of PTO are difficult to be determined because we were unable to characterize PTO precisely. However, the band edge position and the bandgap of PTO were estimated after the previous literatures. The work function (WF) of $\mathrm{PtO}_{x}$ was reported to be $\sim 5.6 \mathrm{eV}$. ${ }^{\mathrm{b}}$ So, we utilized this value, $5.6 \mathrm{eV}$, as the WF of PTO. We can consider that the WF value is the Fermi energy value, which is nearly equal to the energy of valence band maximum in the case of p-type conductor.

The bandgap of PtOx was generally reported by the density functional calculations (DFT). However, the bandgap value depends on the crystal structure, $x$ values, and how they calculate it. ,d $^{\text {d }}$ The bandgap of $\mathrm{PtO}$ with the $\mathrm{GeS}$ structure was calculated to be $0.3 \mathrm{eV}$ using a DFT calculation. For $\mathrm{PtO}_{2}$ in the $\mathrm{CaCl}_{2}-$ type structure, the bandgap was calculated to be $\sim 1 \mathrm{eV}$. The bandgap of $\mathrm{PtO}_{2}$ in the $\mathrm{PbCl}_{2}$ and $\mathrm{CdI}_{2}$ structures have larger bandgaps than that in the $\mathrm{CaCl}_{2}$-type structure. ${ }^{\mathrm{C}}$ In another report, the bandgap of $\alpha-\mathrm{PtO}_{x}$ varies from $\sim 1.3$ to $\sim 1.8 \mathrm{eV}$. For $\beta-\mathrm{PtO}_{2}$, the bandgap was calculated to be $\sim 0.46$ to $\sim 1.8 \mathrm{o} \mathrm{eV}$, and $\sim 1.25 \mathrm{eV}$ when using DFT-GW. ${ }^{\mathrm{d}}$ Here, PTO in the present study would be $\mathrm{PtO}_{x}$, where $x$ value would be 1 or less, so we draw the band structure of PTO on the assumption that the bandgap of PTO is $0.6 \mathrm{eV}$. The band diagrams of $\mathrm{WO}_{3}$ and PTO before and after connecting with each other are shown in Fig. S12a and Fig. S12b, respectively. Electron transfer directions under visible light in generating the n-type and p-type anomalous photo-TE effect are indicated in Fig. S12c and Fig. S12d, respectively. It should be noted that only the directions of dominant electron transfer, responsible for generating the n-type and p-type anomalous photo-TE effect, respectively, are indicated.

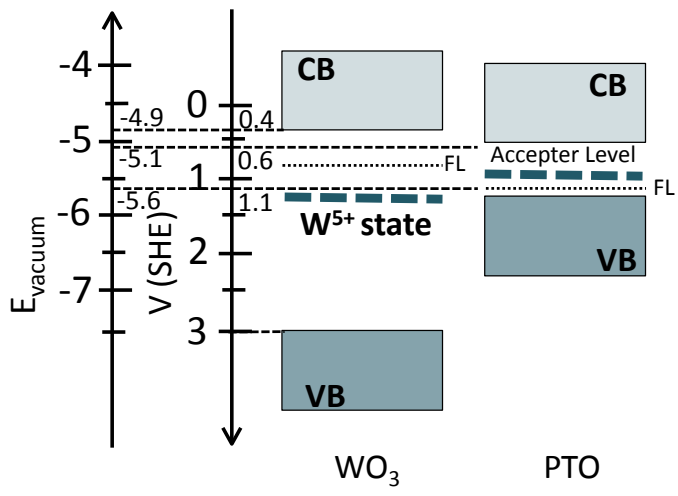

(a)

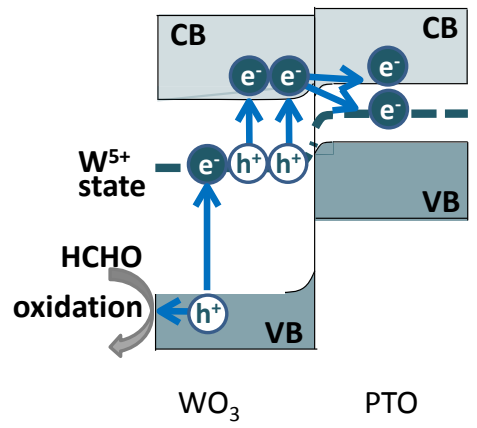

(c)
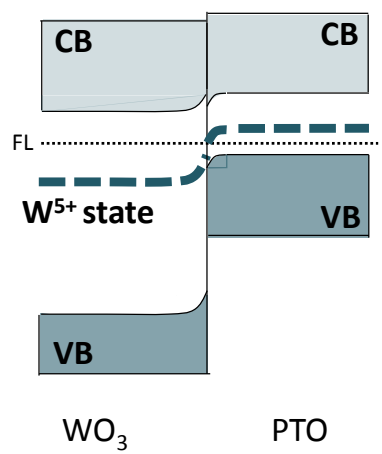

(b)

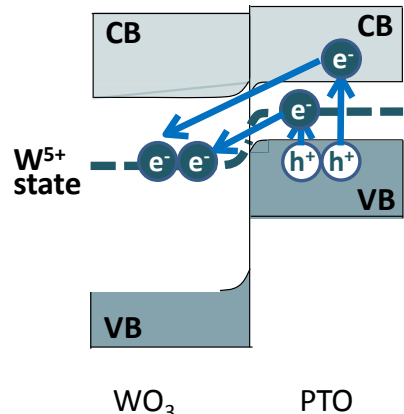

(d)

Figure S12. Band edge positions of $\mathrm{WO}_{3}$ and PTO (a) and band alignments of $\mathrm{WO}_{3}$ and PTO after connecting with each other (b). The charge transfer processes are also shown in (c) and (d). Electron transfer directions under visible light in generating the n-type (c) and p-type (d) anomalous photo-TE effect. 

a) Hashimoto, K.; Kawai, T.; Sakata, T.; J. Phys. Chem., 1984, 88, 4083-4088.
b) Shao, S.; Chen, T.; Huang, S.; Jiang, F.; Wang, Y.; Koehn, R.; RSC Adv., 2o17, 7, 39859-39868.
c) Nomiyama, R. K.; Piotrowski, M. J.; Silva, L. F. Da; Phys. Rev. B, 2011, 84, 100101.
d) Yang, Y.; Sugio, O.; Ohno, T.; AIP Adv., 2o12, 2, 022172. 